EDITOR

Victor S. Zarzycki

Dean of Student Services

Philadelphia College of Art

Broad and Spruce Street5

Philade phia. PA 19102

[215) 893-3186

EOITORIAL BOARD Marge Cibik

Drector of Admissions and

New Student Programs

Northern Arizona University

Flagstaft, AZ 86011

Elizabeth Finlayson

Director. Student Orientation

and Academic Advising

James Madison University

Harrisonburg, VA 22807

Jane Jackson

Assistant Dean of Students

University of Illinois/Urbana-Champaign

Urbana, IL 61801

Nell Glynn Koester

Assoc. Vice-President for Student Adfairs Western Illinois University

Macomb, IL 61455

Donald J. Perigo

Director ol Orientation

University of Michigan

Ann Aroor, MI 48109

Doug Smith

Director of Orientation and Student Advising

University of the Pacific

Stockton, CA 95211

The National Crientaton Directors Association in compliance with Titles VI and VI of the Education Amendments of 1972, and Sections 503 and 504 of the fiehabilitation Act of 1973 , coes not discriminate on the basis of tace, color national crigin, religion, sex, age, or handicap in any of its policies, procedures $\alpha$ practices. This non discrimination policy covers membership and access to assoclation programs and activities including, but nol lim-1ed 10, national conventions, oublications, ecucatonal services, and empoyment.

Inclusion of any article or materials in the NODA Journal does nol constitute endorsement by the National Orentation Drectors Association.

COVER DESIGN: JOAN RODOY, PHILADELPHIA, PA

\section{New Student Orientation on an Urban Commuter Campus}

Urban commuter campuses share many similarities with traditional residential colleges and unversities. While there are similarities, there are also many differences. One of the major differences is the dverse student body on the urban campus and the difficulty in providing necessary services and educational programs. Orientation programming is one of those essential services which need to be provided but which is extremely difficut to schedule. Campus authorities continualy struggle to develop a systematic student orientation program which meets the needs of the students and enables them to successfully prepare for a significant learning experience.

A successlul orientation program depends on two central variables. These variables are time and space. Orientation involves time. Students need time to get acclimated to the campus. They need time to talk to the counselors and to the faculty members. On most residential campuses orientation is scheduled from one to seven days. It is not enough to simply pour information into the student: it is necessary to give the student time to digest it. The student needs time to th nk, to grope, and to eva uate.

The need for time brings in the second variable; space. As the new students come to the campus, they need a place to stay. On residentlal campuses, dormitories are open during the orientation sessions. On many large university camouses, orientation sessions run for days and, for a set fee, students stay in the dorm and attend various sessions and workshops to plan their tuture.

On an urban commuter campus, both of these variables are at a premium, However, they must be considered with regard to the following relevant lactors:

1. Commuter students have simultaneous commitments to work, school, and family. Consequenty they find it unappealing to devote a considerable amount of time attending orientation sessions (Austin, 1975i.

2. Many commuter students are first generation college students and there is no family iradition that reintorces the need for proper preparation and orientation before attending college. Thus, orientation does not seem to be an important activity at least not on the level of attending classes / Hall, 1974; Kasworm, 1980).

3. Students on urban commuter campuses commute and as such are not captive audiences to any presentations made by the University except for the classes they attend.

Dr. Golam Mannan is Dean for Student Services and Associate Professor of Educational Psychology at Indiana University-Purdue University at Indianapolis.

Dr. Gerald C. Preusz is Assistant Professor of Higher Education at Indiana University-Purdue University at Indianapolis. 
4. Since students tend to spend minimum time on campus, any program deve oped must compete with other comm iments. The program mustbe extrinsically remunerative or else the probability of its success will be minimal.

5. A large number of cummuter students tend to be late about making up their minds about going to college. It would be difficult to plan orientation programs for them short of delaying their adm 5 sion process. Thus, the only option avalable to the university is to hat admission after a certain date and admit the late students for the subsequent semester or quarter. In these days of declining enroliments and budgetary retrenchment or downsizing, few campuses would be willing to pursue that end.

The develocment of an orientation program on any urban commuter campus should also be concerned with the following generalized assumptions about the campuses themselves:

1. Usually, physical locations of buildings on an urban campus are not neatly arranged. Therefore, buildings may or may not be easilyaccessible.

2. A tr ly urban commuter campus may be scattered and at times sprawled throughout the city. in order for a student to carefully plan a schedule, he needs to be familiar with the campus. This is especially true when he has limited time for an education, job and other community activities.

3. Development of an on-going student-teacher relationship is hard to evolve, If a protessor is available, the student hardly gets any extra time to pursue a point ask a question or for that matter, socialize. Most student interactions with classmates are superficial and temporary with little opportun ty tor development of close personal relationships. Not unlike sociely in genera, Ioneliness and isolation from other people and students in carticular become a large part of urban college life.

4. There are very few dormitory spaces available on urban commuter campuses. But even if dormitories were available, to have the commuter student leave the familial and job obligations behind and spend days and nights co campus would be inaporopriate and unacceptable. Theretore, the orientation program must be examined in terms of goals and directions more suited to the commuter students.

\section{GOALS OF ORIENTATION}

Orientation brings the university and the new students together. The university has certain expectations of the students; and the students, similarly have some expectations of the university. Orientation is the 1ime to crosscheck these expectations and foster a healty adjustment. The need for this mutual understanding of expectations is especially important on a commuter campus for several reasons:

1. A considerable majority of commuter campus students are marginally precared academically.

2. Increasing numbers of older students are returning to campus and their years of absence has diminished their selt contidence (Lana, et. al, 1979)

3. The older students are not always aware of the demands that the university ecucation places on their intellect, time, ability and resources.

4. Traditionally, the university expects students to be singularly motivated to the goals of higher education. Today, more than ever, the goals of higher education are diversilied and campuses receive large numbers of students whose goal comm itments are marginal and diversified. Theretore, it appears that a review of the objectives of orientation be examined.

\section{SPECIFIC OBJECTIVES OF ORIENTATION}

The specific objectives of orientation can be subdivided into three broad categories:

1. Academic Advising

2. Self and Goal Exploration

3. Orientation to the Campus

\section{Academic Advising}

The primary objective here is:

1. To assess the student's pricr capabilities and academic preparation

2. To ident fy the needed courses consonant with the student's abilities and academic ambitions.

Achievement of these two object ves is not an easy task. It requires rapport and insight. It demands protessional knowiedge, and most importantly, it demands time. Quality academic advisement is a student-centered, developmental process rather than a perscriptive and clerical activity.

\section{Self and Goal Exploration}

Orientation is a time tor exploration. More than anylhing else, the beginning students need to understand their own motivation for higher education. Many times there exists a dissonance between student expectations and the actualities of the educational environment. Students may have inaccurate and/or undefined expectations concerning their own educational goals and intellectual abilities. Furthermore, many students select higher education without a thorough examination of how that experience will enable them to capitalize on thelr own abilities toward the ach ievement of theireducational and life goals.

In many ways the self and goal exploration may form a part of the broader concept of academic advising. However, the importance of this activity should not be minimized by relegating it to a secondary place behind the mechanica process of course selection. Sell and goal exploration is especialy crucial on urban commuter camouses because of the lentative nature of goal commitment which is so pervasive among large numbers of commuter students. A considerable number make up their minds late and their commitment to higher education is exploratory at best.

\section{Orientation to the Campus}

The transition trom high school to college, from the security of a home environment to a campus, can be overwhelming. The objective of an onientation prom should he to help students make this transition an easyone. It should help students develop positive attitudes about the university environment, help students learn the location of various offices that provide services for them, and meet various university personnel who are available to assist them. A university has its own set of academ c guidelines and disciplinary and administrative rules and regulations. Failure to be acouainted with these may cause students undur harcship. It is not uncommon to find that many students lose retund money because they do not pay enough attention to or are not cognizantof the last date of withdrawal from classes without any fee penalty. Sometimes, students do no realize that withdrawal procedures must be initiated before oflicial withdrawal from the university is poss ble. Failure to properly withdraw officially resu ts in a lailing grade.

As incicated earlier, a good crientation is a good beginning for developing a working relationship between the student and the university, It snould be carefuly planned, well-executed, and most of all, it should be incorporated as part of the university's academic process. 


\section{ORIENTATION STRATEGIES ON A COMMUTER CAMPUS}

There is, clearly, no single strategy for orientation on an urban commuter campus. One has to take each cbjective at a time and devise various strategies to achieve the objective. Alternatively, a smorgasboard of strategies may be developed with the hope that students will pick and choose and find what they need. Listed below are several ideas to consider.

1.The In-class Orientation. The first session of each academic semester is usually devoted to orientation to the course. Among other things, the instructor presumably discusses the objectives of the course, the content areas to be covered, the number and nature of tests, and the grading policy. Although it is tempting to start class or the academic lecture right away, the instructor in a freshman class could devote the session to orientation. The instructor could describe the unversity, the academic procedures and policies most pertinent to the student's survival, and then check with each student to see if thereare any lingering questions related to the student's career goal, academic orientation, and academic advis. ing. The objective of th is session would be to set a climate where the student without being rushed into academic lectures, can take time to analyze and comprehend some of the most important steps necessary tor success in college.

One of the chief problems with this system is that many faculty members may notbe disposed to the idea or may not have the necessary training and information to handle such a session. A skill developmentand in formation workshop for faculty might be helpful in solving this problem. Also, Student Services personnel could visit the classes on the invitation of the instructor.

As students move from one class to another, they may find duplication of information. The same questions may be asked of the student in more than one class and the same intcrmation may be given more than once. In reality, this might be he plul. The questions might reintorce their thinking and memory. However, there is another waylhis problem can be resolved. The instructor might excuse the stucients who find the duplica tion unappealing. This will reduce the class size and bring the small group discussion to a manageable level. In a large class, the protesso might recruit the more knowledgeable students to work with him and have several small group sessions at the same time

2. Rolling Orientation Programs. These programs work well for large in man class. Along with their admission notifications, the students could be scheduled for orientation sessions in groups of lifty to a hundred stud. ents. This will maintain the strategy of smal group sessions and possibly of one to one acquaintances even on a large campus. On urban commuter campuses this will not put undue strain on resources, physica space, and time (Henderson, 1980)

However, possible repetilion of the same theme or issues over and over again might tire the crientation personnel. Thus, as time gces by. they may not project themselves and the campus as pos tively as they would have on earlier sessions. The solution to this problem may lie in caretu planning of the orientation dates and efficient rotation of orienta tion personnel. It the sessions are scheduled on dates apart from each other, the problem ot staft routine could be avoided. Where the sessions are scheduled on shorter intervals, different groups of orientation personnel could be recruited from among the faculty and senior students.

A second problem might arise with those who are admitted late. There may not be enough time for orientation before registration. The orientation sessions, in this case, could be organized right after the regis: fration, maybe even during the first week of classes. In a rolling orientation program, it would be possible to identify students who have not attended an orientation session. One can further hope that the number of late admittees would be a manageable one.

3. "One Shot" Survival Sessions. These sessions would be conducted both betore and immediately atter registration. The sessions conducted befcre registration should cover the information necessary fora smooth registration (all the steps the students have to follow, academic advising: fnancial aid procedures, etc.). Also, this session should cover what is expected of the students, and the skills that are necessary for the student's survival at the institution.

A post-registration session should start with a post-mortem of the registration process. This would suggest a student woice in the process plus some valuable evaluation of the system. Also, this session should cover intormation about the various units within the inst tution that can be of help for the student's survival.

4. Orientation Seminars. The concept of an orientation seminar difers from the three approaches above in that this is not a one-time-only occasion. Part of the problem in the three approaches mentioned above lies in the amount of time that can be devoted to each session. The orientation seminar could be used as a healthy altemative to an intensive orientation session lasting for several days. The seminar could be conducted throughout the first semester of enrollment. In some colleges where this type of seminar is used, the seminar is conducted for the tirst halt of the semester. Usualy one to three credit hours are given for the seminar. These seminars cover a whole gamut of student concerns regarding the academic lite of the university. The much needed experiences of self development, value and goal clarifcation and career exploration become basic ingredients of this course (Beck, 1980; Cohen and Jody, 1978: Sagaria 1979.

The orientation seminars could, also, become a useful vehicle to conduct tollow-up of the freshman advising process. It is always important to find out it the initial advising matched the expectations of the students and faired well against the realities of the classroom experiences.

In addition. one can get further ins ight into other variables that are affecting the student's progress planning tor the ensuing semester.

As indicated earlier, there is no sing e orientation process aval able to meet the needs of the diverse student popu ations found on urban commuter campuses. Instead, what is needed is a diverse and varied system of orientation; an orientation procram that has many approaches. Since the problems of timeand space cannot be altered, then the adjustment to those factors must be made by a diverse approach to orientation. Therefore, it is suggested that a combination of the above strategies be developed for a comprehensive program.

\section{BIBLIOGAAPHY}

Abel, J., "A Pilot Project: Intormation Surveys for Continuing Orientation", Joumal of College Student Personnel, 1979.20, pp/ 528-529.

Astin, A. W, Preventing Students From Dropoing Out, Jassey-Bass Publisher. San Francisco, 1975

Beck, M. C, "Decreasing the Risk of High Risk Students", Community and Junior Coliege Joumal, September, 1980, 51, pp. 4-6. 
Betters-Reed. B. "Symoosium for the Future: A Continuing Orientation Program", Joumal of Coliege Student Personnel, 1976, 17, p. 156.

Cohen, R. D. and Jody, R. Freshman Seminar: A New Orientation, Westviaw, Boulder Colorado, 1978. p. 142 .

Daher, D. "College Survival Test: A Structured Intervention for Orientation or Parents' Day Programming', Joumal of College Student Personnel, 1979, 20, pp. $379-381$.

Decouster, 0. led i Student Develooment and Education in Coliege Residence Halis. ACPA, Washington. D. C., 1974, pp, 3-21

Oraper, F. "Student Led Orientation Programs", Joumar of College Student Personnei, $1978,19, \mathrm{pp}, 456-46$ :

Eckstien, D. 'Human Potential Seminars as an Innovative Freshman Orientation", Joumal of Colisge Stuoient Personner, 1977. 18. pp. 241-242.

Hall, L et al, New Calieges for New Students, Jossey-Bass, San Francisco, 1974

Harris, N. H., Strangers in Strange Land. Student Act vities Programming. May, 1980,13, pp, $30-32$

Henderson, C., Retention improvement: Case Studies, Policy Brief, American Council on Education, December, 198, p. 4

Higgins, D. "Providing an Orientation Program for Evening Students", Journal of College Student Personner, 1979, 20, p. 552.

Higginson, L. C., Moore, L. V., and White, E. A, "A New Role for Orientation", NASPA Journal, Summer, 1981, Vol. 19, No. 1, pp. 21-28.

Kasworm C. Z "Student Services for the Older Undergraduate Students", Journal of Coliege Studen! Personnel, March, 1980, 21, pP. 99-102

Knott, E. "A Structured Group Program for New Students", Jouma of Coilege Stwoent Personnel, 1978, 19, pp. 456-461

Kubala, K, "An Academic Advisement System Used to Orient Large Groups of Freshmen' Journal of Coliege Student Personnel, 1979, 20, po. 554-555.

Lance, L Loune, $J$, and Mayo $C$ "Difficultes of Re-entry Students by Sex and Length of School Intern ption", Joumal of National Asscciation for Women Deans, Aoministrators \& Counseiors, Spring. 1979, 42, pp. 39-42.

Sagaria, M.A. D., "Freshman Orientation Courses: A Framework", Journal of the National Association for Women Deans, Administatars \& Counselars 1979

Smith. D.S, "Orientaton Center for University Students", Joumal of College Student Personnei, 1978, 19 pp. 187-188.

Spooner, S, "Simulation Gaming as an Orientation Tool", Joumal of College Stwoent Personnel, $1981,22, \mathrm{pp}, 78-79$.

\section{Orientation Programs and Practices: 1963 - 1981}

\section{INTRODUCTION}

A though orientation seems to be common vernacular among educators, here appears to be some degree of diversity in understanding what specitically is meant by orientation. In one perspective, Mueller (1951) suggests that crientation is the final stage of the overal admissions process. There are others who consider orientation as the beginning of a "continuing" program of personal devel coment of the student. There are those, 100, who view orientation as merely a "Irill" to the educatonal experience.

In a recent study. Moore, et al $(1979)$ ident fed three goals for orientation programs: (1) to ease the entry process with regard to items like placement lests, advising, and registration; 21 to ofter students the opportun fy of realistica ly assessing campus I fe; and $(3)$ to famlliarize students with the student attairs component of the university.

In a more philosophical sense, however, orientation can beviewed as being coth microcosmic and macrocosmic in scope and depth of purpose. (Dannels and Kuh, 1964). Wigent (1971) icentitied the microcosmic programs as those that are crmarly concernec with the student's immediate relationshlo with the institution, while the macrocosmic emphasis is more concerned with helping the new student understand the philosophy and general purposes of higher education.

Perhaps this diversity is more understandable when one considers that wariou s trams of orientation are tound in all wa $k s$ of life and undervarying labe $s$. For instance, the military has boot camp or basic training and business corporations have detailed management trainee programs. No matter what they are labeled, however, the underlying or tundamental purpose is the same: to bridge some existing gap between the familar past and the unfam liar future.

\section{PURPOSE OF STUDY}

The purcose of this research was to follow up a 1963 study of orientation Trams for new students in twelve seiected colleges and universites across the United States. A secondary purpose was to expand the initial survey in order to obtain additional data on orientation practices as well as to increase the sample from the criginal twelve institutions. The 1981 survey resulted in 110 colleges and universities responding to the questionaire.

\section{METHODOLOGY}

The 1963 study involved a survey of twenty colleges and universities selected trom raview ct the literature at that time. The institutions were selected

James Staudenmeier is Associate Director of Aca-

demic Affairs and Joseph J. Marchetti is Assistant Dean of Student Affairs at Pennsylvania State Univer.

sity, Hazleton Campus. 